\title{
An Exploratory Examination of Export Control Act Violations
}

\author{
Joan Wiggenhorn ${ }^{1}$, Kimberly Gleason ${ }^{2} \&$ Manoharlal Sukhwani ${ }^{2}$ \\ ${ }^{1}$ Florida Institute of Technology, USA \\ ${ }^{2}$ University of Pittsburgh, USA \\ Correspondence: Kimberly Gleason, Department of Finance, Clinical Associate Professor of Finance, \\ University of Pittsburgh, USA. E-mail: gleasonk@pitt.edu
}

Received: January 3, 2014

Accepted: February 25, 2014

Online Published: March 26, 2014

doi: 10.5539/ibr.v7n4p101

URL: http://dx.doi.org/10.5539/ibr.v7n4p101

\begin{abstract}
This paper examines the impact of violations of export control policy from a multinational enterprise's perspective. We describe the kinds of regulation in place in the U.S. over the past decade, and identify the characteristics of firms who have been caught and fined for violations of export restrictions. Furthermore, we investigate the response of shareholders to news regarding trade violations and find that they suffer a statistically significant $-1.15 \%$ abnormal returns over the three day announcement window. Not surprisingly, we find that the reaction post 9-11 is worse as is the reaction when the export violations occur with countries perceived to be corrupt. We also find that systematic risk and total risk increase for violators following their investigations. Further, any penalty in terms of long run performance for ECA violations is limited to those violations with the "corrupt" countries.
\end{abstract}

Keywords: export control act, event study, ECA violations, risk changes

\section{Introduction}

Following the attacks on the World Trade Center on September 11, 2001, a tremendous amount of reassessment of American foreign policy has taken place by the U.S. citizenry, regulatory institutions, and political participants. National attention has also been drawn to the role of trade as an instrument of political policy. Well known examples of current uses of trade as foreign policy weapons include the U.S. embargos against Cuba, Libya, North Korea, Iran, and the Iraqi Baa'thist regime under Saddam Hussein. While some trade restrictions are directed at individual countries as those just mentioned, others restrict the sale of "high tech" exports to a large number of countries, even allies; and finally, some restrictions apply not just to countries, but to particular individuals. In 2008, under President Bush, there was a directive on reforming export controls with new regulations and revisions. The directive focused more on individuals and entities rather then entire countries and particularly focuses on high technology dual-use items (Bartlett et al., 2009).

However, there have been numerous instances in which U.S. firms have been hurt by trade restrictions, particularly when used for foreign policy rather than national security purposes. Export control costs occur due to export losses to companies from blocked contracts, and from foregone future business opportunities, and FDI reductions (Nollen, 1987). One study in 1987 estimated that U.S. exporters lost $\$ 9.3$ billion in sales annually because of the delays and uncertainty of the export licensing system (Erickson, 1997). Nollen (1987) estimates that the long run and indirect loss to American companies that were involved in the Soviet gas pipeline controls were between $\$ 3.6$ and $\$ 4.1$ billion over a six year period.

The need for some type of export restrictions is generally accepted, but the difficulty in enforcing the existing restrictions and anticipating which restrictions are needed is apparent. There may be an inherent conflict between a company's focus on profits and the need to protect national security. Burris (2010) examines the export control debate using the U.S. commercial satellite industry. While there is an acknowledged need to keep space technology away from possible enemies, one also has to acknowledge that too draconian an export control policy will harm the U.S. space companies. So a balance must be achieved. In testimony before the House Subcommittee on Terrorism on July 9, 2009, Arthur Shulman, the General Council for the Wisconsin Project on Nuclear Arms Control, addressed the importance of strong and effective export controls for U.S. national security, the necessity of addressing the risks of transshipment and diversion at home and abroad, and the need to improve industry's ability to police itself. 
However, it is not always apparent which companies are violating the Export Administration Regulations (EAR). In general, there are many legal and political issues when conducting international trade. Sakchutchawan (2009) provides a review of the literature about the many trade finance difficulties as well as regulations that firms face. Cinelli and Huffman (2006) warn that outsourcing may result in firms violating export restrictions. Computer companies may use third parties to manufacture hardware or write software. Cinelli and Huffman (2006) as well as McQuade and Geren (2006) warn that the use of off-shore preparation of U.S. patent applications may also violate security laws. Even universities are not exempt. A 2006 GAO report found that while most universities focus on fundamental research which is published, government officials were concerned that in some cases foreign students were involved in research that would violate the EAR (Export Controls, 2006). For companies, even if they do not have any international business whatsoever, they may still have to restrict the access its foreign national employees are given to certain technical data (Hunt, 2005).

The fines imposed when companies are found to have violated trade restrictions can be significant. In 2003, Raytheon agreed to pay \$25 million in civil fines to settle federal charges that, from 1990 to 1997, it tried to evade export laws in the attempted sale of sensitive radio equipment to Pakistan. In 2007, I.T.T. Corporation pled guilty to multiple criminal charges of the Arms Export Control Act as a result of selling high technology night vision equipment to Indian companies. The fine was a $\$ 100$ million settlement, and the NV division was prohibited for three years from participating in exporting defense articles or furnishing defense services (Waite \& Schwartz, 2007). More recently, a Texas firm, Weatherford, was given the largest civil penalty ever levied by the Commerce Department's Bureau of Industry and Security which is tasked to review violation of the Export Administration Regulations. As the Under Secretary Hirschhorn stated: Serious consequences ensue when companies evade U.S. sanctions and export controls" (Texas Company, 2013, p. 1). Weatherford's violations occurred between 2002 and 2007 and included exporting oil and gas equipment to Iran through the UAE, and similar equipment to Cuba via Canada.

In light of both the need for some export controls and the desire of U.S. firms to have the fewest restrictions possible, we believe that this paper uniquely examines the wealth effect on stockholders of violations of export restrictions. We describe the kinds of regulation in place in the US over the past decade, and identify the characteristics of firms who have been caught and fined for violations of and export restrictions. Furthermore, we investigate the response of shareholders to news regarding trade violations. We find that the impact on firms found violating the EAR can significantly exceed that of the fines alone. On average, the abnormal return over the three day window of the announcement is $-1.15 \%$. Additionally, the returns are worse post $9-11$ and for violations involving countries that are considered corrupt.

The rest of the paper is organized with the Literature Review first. This is followed by the Hypotheses section, and then a description of the firms found in violation of the Export Control Act. We next describe both the event study and long run performance methodology. Following this are the Results and finally the Conclusion and suggestions for further research.

\section{Literature Review}

\subsection{Corporate Social Responsibility and Corporate Illegalities}

Corporate Social Responsibility (hereafter, CSR) refers to an ethical responsibility of managers to act in the interest of both shareholders and other stakeholders. It has been defined in the literature as "situations where the firm goes beyond compliance and engages in 'actions that appear to further some social good, beyond the interest of the firm and that which is required by law' (McWilliams, Siegel, \& Wright, 2006). Broadly speaking, these stakeholders include consumers, the environment, fair workers, communities, and society at large. Evidence suggests that a focus on CSR benefits both shareholders and other stakeholders of the firm For instance, Dhaliwal et al. (2011) documents that firms that disclose CSR activities voluntarily exhibit a lower cost of equity capital.

At the other extreme, studies examine corporate criminal liability as well. While some offenses, such as fraud, theft, tax violations, bribery and antitrust violations have quantifiable fine provisions, there are no such provisions for most environmental, food and drug, and export control violations (Viano \& Arnold, 2006). Baucus (1989) notes "these questions are of interest and great importance not only to researchers but to lawmakers, managers, and the public in general". To the best of our knowledge, this study is the first to examine the short term and long term stock price effects of export control act violations. While there is some qualitative literature about violations of export restrictions (Czinkota \& Dichtl, 1995), we also draw upon the literature on the market's response to corporate illegality.

Davidson et al. (1994) and Davidson, Worrell and Lee (1994) use event study methodology to examine 
announcements of corporate criminal activity, which they define as "social irresponsibility". They find a negative market reaction to corporate illegalities, particularly to repeat offenders. Karpoff and Lott (1993) examine instances of corporate fraud and find a negative stock price reaction, which is particularly pronounced when the fraud is committed against government agencies, and Karpoff, Lee, and Martin (2011) find large, significant negative abnormal returns to firms prosecuted for foreign bribery. Expanding their study to include data from 1978-2013, they find that over $20 \%$ of firms with foreign sales have violated the FCPA for bribery at least once (Karpoff et al., 2013).

However, none of these studies investigated corporate crime in the form of export control violations. In a meta-analysis, Frooman (1997) evaluates 27 prior event studies that measured the stock market's reaction to incidences of socially irresponsible and illicit behavior. He finds that shareholder wealth decreases are statistically significant. He also finds that for the sample for illegal behavior is more negative than that for what he calls "irresponsible behavior".

\subsection{Corporations and Government Export Policy}

Governments often implement policies designed to encourage exports, and these policies generally represent opportunities for firms to develop new markets, although literature on the cross-sectional impact on firms is scarce. Freixanet (2011) finds that export promotion programs overall facilitate exports and tend to benefit firms in the initial export stages. Wilkinson and Brouthers (2006) find that SME outcomes are positively enhanced by US state-sponsored export promotion strategies. However, while there is literature that focuses on export promotion, we believe that this is the first paper to examine the effect on stock prices from violations of the Export Control Act. We next review the provisions of the Act and its impact on US firms.

The US Department of Commerce's Bureau of Industry and Security (BIS) handles enforcement of import-export restrictions for reasons of national security, foreign policy, and nonproliferation - falling under the category of Export Administration Regulations (EARs). (Note 1)

Investigation and prosecution of potential violators is conducted by the US Department of Justice, with the support of the BIS Export Enforcement Special Agents unit. The BIS also provides a database of regulations, as well as a list of names of "Denied Persons" with whom American entities cannot engage in import-export activities. Managers of international businesses who plan to engage in import-export activities are responsible for putting controls in place to ensure that the myriad of restrictions are not violated. Burke et al. (2009) provide a detailed qualitative analysis of export controls and their effect on business operations. They emphasize that the EAR is particularly concerned with "dual use" items in which commercial products also have a potential military use. One prominent example involves encryption items since they can potentially hurt national security. Morris (2006) stresses the importance of executives in culturing export control compliance. Penalties are also dependent on eight aggravating factors and nine mitigating factors. Of these nine, the two given greatest weight are voluntary self disclosure of the violation and the company's having an effective export compliance culture.

The primary kind of restriction is prohibitions on certain goods, such as high-tech items chemicals that could be used in the development of weapons. For example, the US Chemical Weapons Convention (CWC) prohibits firms worldwide from exporting a wide range of substances. The CWC Export Administration Regulations are quite complex, and compliance - recordkeeping, reporting, and disclosure on behalf of exporting companies is expensive and cumbersome. Firms violating Export Administration Regulations are subject to both criminal and administrative prosecution, and penalties ranging from fines varying with the severity of the violation to revocation of export privileges. Another example are the multilateral export control agreements in which the US participates, such as the Wassenaar Arrangement on Export Controls for Conventional Arms and Dual Use Goods and Technologies, the Missile Technology Control Regime, the Nuclear Suppliers Group, and the Australia Group, which focuses on chemical exports that may become weapons in the future.

Exports with "denied parties" are a second category of criminal offenses related to trade. The BIS maintains its list of denied persons, as well as an Exports Administration Regulations' Entity List, of organizations suspected of facilitating the proliferation of weapons of mass destruction; the US Treasury has a Specially Designated Nationals and Blocked Persons List, consisting of persons suspected of narcotics trade or terrorist financing. In "Fines for the Unsuspecting", Rogers (2006) warns that it is important to know with whom you are doing business. For instance, all Cubans aren't listed individually on the SDN list, but a transaction with any Cuban national is prohibited unless given an exemption by the Treasury. More recently, President Bush's directive in 2008 focused more on individuals and entities and less on countries (Barlett et al., 2009).

Violations of U.S. or U.N. embargoes are prosecutable under law; exports and re-exports to and from Iran, Iraq, Afghanistan, Angola, Libya, North Korea, Rwanda, Sudan, Syria are severely restricted, if not prohibited. The 
Treasury maintains a separate list of countries, including Burma, the Balkans, Liberia, and Zimbabwe, and industries and activities, such as diamond mining, narcotics trafficking, proliferation of nuclear weapons, under sanction or forbidden by US regulation. The denied persons, entity, embargoed, and sanctioned lists are all updated as information regarding threat potential or human rights situations changes.

Jeffrey Bialos (1989) highlights some of the difficulties in the detection and disclosure of violations of U.S. export controls. Since the process depends on voluntary disclosure by a firm, when a company learns that it may have violated U.S. export controls it must first decide what type of internal investigation to conduct and what processes to adopt. In 2013, the State Department and Meggitt-USA reached a settlement in a case that went back to the 1990s. It mainly involved unauthorized export of defense items or data. Meggitt disclosed their violaions voluntarily and hence their fines may be reduced from $\$ 25$ million to only $\$ 3$ million due to their cooperation (Department of State, 2013) Thus, initial remedial measures can mitigate potential sanctions and demonstrate a commitment to compliance with U.S. export control laws. Erickson (2014), in a study of arms embargoes, finds that while not eliminating all arms sales, embargoes do have a positive effect in restricting the flow of arms to restricted countries.

In our study, we examine a sample of 75 export violations. If we assume that criminal activity conducted by the firm or employees on behalf of the firm is profitable, then criminal activity should increase owners' wealth as long as the crime goes undetected. However, when the criminal activity has been discovered, the firm may face several costs including fines, legal fees, lost employee time (spent fighting the charges), and negative publicity. While the criminal activity may have been profitable, "getting caught" will certainly not be and should result in a negative stock price reaction.

\section{Hypotheses}

Given that most studies (Davidson \& Worrell, 1988; Karpoff \& Lott, 1993; Davidson,Worrell, \& Lee, 1994) find a negative stock price reaction to announcements of corporate illegality, we expect:

H1: The announcement of export violations by corporations will be accompanied by negative abnormal returns.

There also appear to be factors which either strengthen or mitigate the negative announcement returns.. Karpoff, Lee, and Martin (2011) find that when charges of financial misconduct in addition to bribery are reported, the share price response is especially pronounced. Block (1991) argues that penalties assessed against a corporation for detected violations are important because they affect a firm's future calculations for possible violations. Baucus and Baucus (1997) also document a negative stock price reaction to multiple convictions, and to more serious offenses.

One factor which has been found to be significant for multinational firms is the impact of the level of corruption in the foreign countries in which they are doing business. Two papers examine the relationship between government corruption and multinational joint ventures (Gleason et al., 2005; Meschi, 2009). Wei (2000) examines local corruption and global capital flows while Robertson and Watson (2004) examine corruption and the impact of FDI. Thus, since a stigma effect has been found in previous studies, it would seem to follow that:

\section{H2: Announcement effects will be more negative for violations with countries that are viewed as corrupt.}

Karpoff and Lott (1993) argue that the "reputational cost of corporate fraud is large and constitutes most of the cost incurred by firms accused or convicted of fraud" (p. 758). These reputational effects may be long-lasting. Baucus and Baucus (1997) also examine the longer term performance effects of corporate illegality and show that firms experience lower accounting returns over five years and slower sales growth in the third through the fifth year. Although they do not find significant poorer long run stock performance, part of the problem may be in measuring long run abnormal returns. Hence, acknowledging the difficulties in measurement, we still hypothesize that:

\section{H3: Firms with export violations will suffer long term performance effects.}

The last consideration is whether or not firms that have violated the ECA will then have greater risk. Given the unfavorable publicity and investors' possible reaction to the news, it is possible that these firms will then have greater overall risk as measured by the variance and greater systematic risk as measured by the firm's beta coefficient.

\section{H4: Firms with export violations will experience an increase in both total risk and systematic risk.}




\section{Data and Methodology}

\subsection{Sample Selection}

The original data set of violations of import export restrictions was obtained from the U.S. Department of Commerce Bureau of Industry and Security for the years 1980-2010. To identify the addition details of the violation, newswire releases for each incident of illegality were obtained from Lexis Nexis and examined to discern the type of infraction, the outcome and the penalty imposed. For a firm to be included in the study, its stock had to be listed on the New York, or NASDAQ Stock Exchanges. This criterion serves two purposes. First, it ensures that the stock is traded frequently enough for market model parameters to be estimated. Second, we require the firm to have returns data available from the Center for Research in Security Prices (CRSP). Accounting data is obtained from Standard and Poor's Research Insight.

Table 1 provides the sample breakdown by year and SIC code.

Table 1. Sample of export control act violations

Panel A. Distribution by year

\begin{tabular}{lll}
\hline Year & $\begin{array}{l}\text { Number of } \\
\text { Violations }\end{array}$ & $\begin{array}{l}\text { Percent of } \\
\text { Violations }\end{array}$ \\
\hline 1995 & 2 & 2.67 \\
1996 & 8 & 10.67 \\
1997 & 4 & 5.33 \\
1998 & 5 & 6.67 \\
1999 & 7 & 9.33 \\
2000 & 3 & 4.00 \\
2001 & 4 & 5.33 \\
2002 & 2 & 2.67 \\
2003 & 2 & 2.67 \\
2004 & 6 & 8.00 \\
2005 & 6 & 8.00 \\
2006 & 9 & 12.00 \\
2007 & 7 & 9.33 \\
2008 & 2 & 2.67 \\
2009 & 6 & 8.00 \\
2010 & 2 & 2.67 \\
Total & 75 & $100 \%$ \\
\hline & & \\
\hline
\end{tabular}

Panel B: Distribution by SIC code

\begin{tabular}{lll}
\hline SIC & $\begin{array}{l}\text { Number of ECA } \\
\text { Violations }\end{array}$ & \% of ECA Violations \\
\hline 1000 & 1 & 1.33 \\
2000 & 9 & 12.00 \\
3000 & 35 & 46.67 \\
4000 & 5 & 8.00 \\
5000 & 4 & 5.33 \\
6000 & 3 & 4.00 \\
7000 & 4 & 5.33 \\
8000 & 0 & 0.00 \\
9000 & 3 & 4.00 \\
N/A & 11 & 14.67 \\
Total & 75 & $100 \%$ \\
\hline
\end{tabular}

The table indicates that there were ECA violations over the entire 16 year period with $44 \%$ occurring prior to 9-11-2001. However, nearly half of all the violations occurred during the four year period from 2004 through 2007. Concerning the SIC codes, almost half of the violations were for SIC codes in the 3000s. This is not surprising since these SIC codes include fabricated metal products, industrial machinery and equipment, electrical and electronic equipment and instruments and related products that include search, detection, navigation, guidance, aeronautical, and nautical systems and instruments. 
Table 2. Descriptive characteristics of offenders

\begin{tabular}{ll}
\hline Variable & Mean (Median) \\
\hline Assets (\$millions) & $\$ 47.18$ \\
& $(19.63)$ \\
Market Value (\$millions) & $\$ 28.18$ \\
& $(\$ 26.02)$ \\
ROA & 2.29 \\
& $(4.41)$ \\
ROE & 29.38 \\
& $(3.85)$ \\
Debt to Total Assets & 18.02 \\
Cash and Cash Equivalents to & $(14.78)$ \\
Total Assets & 13.36 \\
\hline
\end{tabular}

This table documents the mean and median values for the corporate partner in the joint venture in the year of the acquisition. Accounting data are obtained from S\&P Research Insights.

Regarding the characteristics of the offending companies, while the asset size varies (as evidenced by the difference between the mean and median), the mean and median market value of the firms involved are about \$28 million dollars. They tend to be profitable as both the ROA and ROE attest, but there is considerable variation in the ROE percentages.

\subsection{Event Study Analysis}

The major purpose of this study is to determine the stock market's reaction to the announcements of violations of Export Control Restrictions. Event study methodology is used. We calculate daily excess (abnormal) returns by using the ordinary least squares market model to specify the expected returns generating process, and then subtracting the actual return on that day. We estimate the market model parameters from period from $t=-110$ to $t=-11$ relative to the announcement day $t=0$. The average excess return for any day is calculated by summing over the ARs for the $\mathrm{N}$ firms in the sample and dividing by $\mathrm{N}$. The cumulative average excess returns (CARs) over a multi-day event period are calculated by summing the average excess returns over the $\mathrm{T}$ day event window.

We employ the standardized cross-sectional residual method of Boehmer, Musumeci and Poulsen (1991) using Scholes-Williams (1977) betas to test for the significance of abnormal returns.

\subsection{Multivariate Analysis of Losses to Violators}

To test for the factors that affect the size of the abnormal returns, regressions are run using the short run abnormal returns as the dependent variable. Some of the independent variables measure firm specific factors, while another measures the overall perception of corruption of the foreign country involved.

The regression equation is:

$$
C A R_{j}=\beta_{0}+\beta_{1} 911+\beta_{2} \text { Corruption }+\beta_{3} \text { Size }+\beta_{4} R O A+\beta_{5} \text { Debt }+\beta_{6} \text { Tech }
$$

Where:

$\boldsymbol{C A} \boldsymbol{R}_{\boldsymbol{j}}=$ the Cumulative Abnormal Returns for announcement returns;

$\mathbf{9 1 1}=$ September 11, 2001; a dummy variable $=1$ if the violation occurred post 9/11 and 0 otherwise;

Corruption $=$ a dummy variable $=1$ if the country in which the violation occurred ranked lower than the median nation in the Transparency International index (representing high corruption), and 0 otherwise;

Size $=\log$ of the market value of the violating firm;

$\boldsymbol{R O A}=$ the Return on Assets of the violating firm, a measure of its profitability,

Debt $=$ Debt/Equity ratio of the violating firm, 
Tech $=$ a dummy variable $=1$ if the firm is a technology firm, 0 otherwise.

\subsection{Analysis of Long Run Returns}

We further investigate the post-conviction performance of firms violating the Export Control Act. The long run stock performance is examined using the Fama-French 3 factor model. Long run performance has been measured using the Fama-French 3 factor model (Yook, 2010; Hyland, 2008; Ferreira, Sinha, \& Varble, 2008) and it is this model that we use. Thus, we calculatelong-run returns using the Fama-French (1993) three factor model:

$$
R_{p, t}-R_{f, t}=\alpha+\beta\left(R_{m, t}-R_{f, t}\right)+s S M B_{t}+h H M L_{t}+\varepsilon_{p, t}
$$

Where:

$\boldsymbol{R}_{p, t}$ is the event portfolio's return in month $\mathrm{t}$.

$\boldsymbol{R}_{\boldsymbol{f}, t}$ is the 1 month Treasure bill rate, observed at the beginning of the month.

$\boldsymbol{R}_{\boldsymbol{m}, \boldsymbol{t}}$ is the monthly market return in month $\mathrm{t}$.

$\boldsymbol{S M T} \boldsymbol{T}_{\boldsymbol{t}}$ is the average return on small market capitalization portfolio minus the average return on a large market-capitalization portfolio.

$\boldsymbol{H M L} \boldsymbol{L}_{t}$ is the average monthly return on a high book-to-market equity portfolio minus the average monthly return on a low book to market equity portfolio.

\subsection{Risk Assessment}

Any investigation into the effects of export violations should include whether the subsequent reactions lead to higher systematic risk to shareholders. First, we compute the total risk as measured by the standard deviation of returns for periods extending 6 months before and after the determination of the export violation. We then define and calculate systematic risk, or beta, which measures the covariance of an asset's returns with that of the market. Systematic risk is important to shareholders, because it reflects risk that shareholders can not diversify away, and returns that shareholders earn on stocks that they hold should compensate them for this risk.

\section{Results}

\subsection{Event Study Results}

Table 3 provides the results of the event study for both the full sample of Export Control Act violators, and for the previously described subsamples.

Table 3. Wealth effects of trade violations

\begin{tabular}{lllll}
\hline Sample Type & No. & $\mathbf{( 0 , 0 )}$ & $\mathbf{( - 1 , + 1 )}$ & $\mathbf{( - 1 , 0 )}$ \\
\hline Full Sample & 75 & -0.41 & -1.15 & -0.65 \\
& & $(-1.14)$ & $(-2.73)^{* * *}$ & $-1.11)$ \\
Pre 9/11 & 33 & 0.13 & -0.05 & $(-1.22)$ \\
& & $(0.51)$ & $(-1.06)$ & -1.21 \\
Post 9/11 & 42 & -0.83 & -1.28 & $(-1.85)^{*}$ \\
& & $(-2.19)^{* *}$ & $(-2.02)^{* *}$ & 1.55 \\
T-stat (Post vs pre 9/11) & $1.88^{*}$ & $2.27^{* *}$ & -2.66 \\
High Corruption & -2.23 & -2.71 & $(-2.27)^{* *}$ \\
(based on median value for & 46 & $(-2.57)^{* *}$ & $(-2.04)^{* *}$ & 0.34 \\
Transparency International) & & & 0.10 & $(1.38)^{*}$ \\
Low Corruption & 29 & 0.70 & $(1.04)$ & $2.16^{* *}$ \\
\end{tabular}

Note. $*$ indicates $10 \%$ significance; $* *$ indicates $5 \%$ significance $* * *$ indicates $1 \%$ significance. 
This table provides the cumulative abnormal returns upon announcement for the $(0,0)$,

$(-1,0)$, and $(-1,+1)$ event windows. Abnormal returns are calculated using the market model estimated from 110 to 11 days prior to the event announcements. CARs represent the cumulative market model-adjusted abnormal returns over the relevant event window. The CRSP equally-weighted market index is used. Announcements of trade violations are obtained from Lexis Nexis and the BEA website. Stock price data are taken from CRSP; accounting data from S\&P Research Insights.

The results in Table 3 indicate that violations of the export control act, overall, are viewed negatively by the market, resulting in a $1.15 \%$ loss of shareholder value over the $(-1,+1)$ event window, significant at the $1 \%$ level. While the results for pre $9 / 11$ are insignificant, post $9 / 11$ are negative and significantly different from the pre $9 / 11$ results. We also run tests on the returns based on the corruption perception of the foreign firm involved. Here, as one might expect, the returns are over $-2 \%$ for all three windows for the high corruption countries and in general insignificant or even positive over the two day window. However, the difference between the means for the two groups of countries is statistically significant.

Table 4. Sources of violators' losses for ECA violations

\begin{tabular}{llll}
\hline & Model 1 & Model 2 & Model 3 \\
\hline Constant & 0.040 & 0.036 & 0.047 \\
& $(1.89)^{*}$ & $(1.74)^{*}$ & $(1.76)^{*}$ \\
911 & -0.023 & -0.028 & -0.025 \\
Corruption & $(-2.01)^{* *}$ & $(-2.378)^{* * *}$ & $(-2.03)^{* *}$ \\
& -0.038 & -0.041 & -0.038 \\
Size & $(-3.28)^{* * *}$ & $(-3.57)^{* * *}$ & $(-3.28)^{* * *}$ \\
& -0.004 & -0.006 & -0.005 \\
ROA & $(-0.81)$ & $(-1.06)$ & $(-0.86)$ \\
& -0.039 & -0.008 & -0.04 \\
Debt Ratio & $(-1.01)$ & $(-0.19)$ & $(-1.01)$ \\
& & 0.064 & \\
Tech & & $(1.68)^{*}$ & \\
F & & & -0.006 \\
N & & & $(0.66)$ \\
\hline
\end{tabular}

Note. $*$ indicates $10 \%$ significance; $* *$ indicates $5 \%$ significance $* * *$ indicates $1 \%$ significance.

This table provides the results of multivariate regression where the dependent variable, $\mathrm{CAR}_{\mathrm{j}}=\mathrm{Abnormal}_{\mathrm{R}}$ Return for the two day window, $(-1,0)$ for each firm. 911 is a dummy variable equal to 1 if the announcement occurred after $9 / 11,0$ otherwise; Corruption is a dummy variable $=1$ if the country in which the violation occurred ranked lower than the median nation in the Transparency International index (representing high corruption), and 0 otherwise; Size $=$ the $\log$ of the market value of the firm; ROA $=$ the return on assets of the firm; Debt Ratio $=$ the Debt/Equity ratio of the firm; Tech is a dummy variable $=1$ if firm is in a technology industry, 0 otherwise. Stock price data are taken from CRSP; accounting data from S\&P Research Insights.

We next investigate the returns using a multivariate analysis. We present three models showing the individual contributory effect for the independent variables. They essentially confirm the univariate results. The dummy variable for the $9 / 11$ variable is negative and significant, meaning that violations post $9 / 11$ involve a higher market penalty. The coefficient for the corruption variable is also negative and significant as were the univariate results. This suggests that when U.S. firms violate the ECA by selling forbidden exports to countries viewed 
unfavorably, the market penalizes those firms more. The coefficients for both the profitability variable and the technology variable are insignificant. The debt ratio coefficient is positive and significant which is somewhat puzzling, as greater creditor monitoring should be tied to larger penalties for such violations.

\subsection{Long Run Performance}

The long run return results are presented in Table 5 .

Table 5. Long run performance of ECA violators

\begin{tabular}{lllll}
\hline & $\mathbf{( 0 , 6 )}$ & $\mathbf{( 0 , 1 2 )}$ & $\mathbf{( 0 , 1 8 )}$ & $\mathbf{( 0 , 2 4 )}$ \\
\hline ECA & 6.72 & 2.13 & 3.65 & 5.64 \\
$(\mathrm{~N}=72)$ & $(2.17)^{* *}$ & $(0.49)$ & $(0.69)$ & $(0.91)$ \\
Pre-9/11 & 5.58 & -1.03 & 2.24 & 2.23 \\
$(\mathrm{~N}=31)$ & $(1.25)$ & $(-0.16)$ & $(0.29)$ & $(0.25)$ \\
Post 9/11 & 7.60 & 4.58 & 4.75 & 8.29 \\
$(\mathrm{~N}=41)$ & $(1.82)^{*}$ & $(0.69)$ & $(0.40)$ & $(0.89)$ \\
T-test (Post - Pre 9/11) & 1.25 & $2.26^{* *}$ & 1.50 & $1.74^{*}$ \\
High Corruption & -2.73 & -6.74 & -9.83 & -15.58 \\
(N=46) & $(-0.37)$ & $(-1.17)$ & $(-1.95)^{*}$ & $(-2.14)^{* *}$ \\
Low Corruption & 9.01 & 10.43 & 12.96 & 27.69 \\
(N=29) & $(1.63)$ & $(2.00)^{* *}$ & $(2.59)^{* * *}$ & $(2.74)^{* * *}$ \\
T-test (High - Low 9/11) & -1.26 & -1.40 & $-2.27^{* *}$ & $-3.05^{* * * *}$ \\
\hline
\end{tabular}

Note. $*$ indicates $10 \%$ significance; $* *$ indicates $5 \%$ significance *** indicates $1 \%$ significance.

The returns are calculated using the Fama-French three factor model using the formula:

$$
R_{p, t}-R_{f, t}=\alpha+\beta\left(R_{m, t}-R_{f, t}\right)+s S M B_{t}+h H M L_{t}+\varepsilon_{p, t}
$$

Where $\mathbf{R}_{\mathbf{p}, \mathbf{t}}$ is the event portfolio's return in month $\mathrm{t}$; $\mathbf{R}_{\mathbf{f}, \mathrm{t}}$ is the 1 month Treasure bill rate, observed at the beginning of the month; $\mathbf{R}_{\mathbf{m}, \mathbf{t}}$ is the monthly market return in month $\mathbf{t} ; \mathbf{S M T}_{\mathbf{t}}$ is the average return on small market capitalization portfolio minus the average return on a large market-capitalization portfolio; $\mathbf{H M L}_{\mathbf{t}}$ is the average monthly return on a high book-to-market equity portfolio minus the average monthly return on a low book to market equity portfolio. The $t$ statistic is given in the parentheses Stock price data are taken from CRSP; accounting data from S\&P Research Insights. They strongly indicate that firms that violate the Export Control Act are not penalized by the market in the long run. Except for the six month window, all the results are insignificant, though positive. These results suggest that, on the whole, there is no penalty in terms of long term performance of violators, supporting the "business as usual" conjecture. The pre 9/11 and post 9/11 results are even more puzzling. In the post $9 / 11$ period results are significantly higher than during the pre-9/11 period. Concerning the High Corruption versus Low Corruption results, high corruption is significantly negative, as expected, but the results for Low Corruption are remarkably high. Apparently from one year to two years after the violation, if the country involved was not seen to be corrupt with no apparent security risk, than the company involved experienced significant positive returns.

\subsection{Risk Shifts}

The last tests which are conducted involve changes in risk. The results presented in Table 6 are as expected. Those firms that violate the ECA experience both higher total risk as measured by the standard deviation and higher systematic risk as measured by Beta. The differences between the before and after risk measures are both significant. 
Table 6. Risk shifts following ECA violations

\begin{tabular}{lll}
\hline & Change in Total Risk & Change in Systematic Risk \\
\hline ECA firms & 0.009 & 0.114 \\
& $(4.22)^{* * *}$ & $(3.57)^{* * *}$ \\
\hline
\end{tabular}

Note. $* * *$ indicates $1 \%$ significance.

This table provides the difference in total and systematic risk over the first year following the violation. Stock price data are taken from CRSP; accounting data from S\&P Research Insights.

\section{Discussion and Conclusions}

In this paper, we examine the market reactions to violations of the Export Control Act. Our results indicate that the market reacts negatively to such violations, and that when these violations are announced, shareholders experience a statistically significant loss in market value. Our results are consistent with the findings of Davidson and Worrell (1988), Karpoff and Lott (1993), Davidson, Worrell and Lee (1994), Frooman (1997), and Karpoff et al. (2011) in that the market acknowledges value loss from the release of news of firm illegality. Our results are also consistent with the conjecture that attempting to "win by cheating" yields negative results for shareholders, and that a penalty will be imposed. The implications for executives are that the top management team will have to evaluate the tradeoffs inherent in potentially being caught exporting prohibited items against revenue from such sales. There are several issues which merit additional study. Godfrey, Merril and Hansen (2009) find that certain types of CSR create goodwill which lessens the impact of negative legal/regulatory actions. It would be useful to find if firms that are guilty of export violations can also mitigate the negative announcement returns. This issue seems particularly relevant given our long term results that firms that sold to countries with low corruption did well a year after the violation. It is also possible that violations involving national security pay a heavier price than those ad hoc export controls supporting temporary foreign policy. One last reason for the differences in long term results may be the amount of additional media coverage a particular infraction receives. It may be that violations involving "corrupt" countries continue to receive press coverage while others do not. Given the large differences in the two subsamples, this might be an appropriate follow-up study.

\section{References}

Bartlett, J., Chapman, J., Hayes, J., Rathbone, M., Vorwig, P., Lichtenbaum, P., \& Sullivan, S. (2009). Export controls and economic sanctions. The International Lawyer, 43, 311-333.

Baucus, M. S. (1988). Who commits corporate wrongdoing: Predicting illegal corporate behavior using event history analysis. Academy of Management Best Papers Proceedings, 160-164.

Baucus, M., \& Baucus, D. (1997). Paying the piper: An empirical examination of longer term financial consequences of illegal corporate behavior. Academy of Management Journal, 40, 129-151. http://dx.doi.org/10.2307/257023

Bialos, J. (1989). The detection and disclosure of violations of U.S. export controls: Management choices and their national security implications. Virginia Journal of International Law, 29, 567-620.

Block, M. (1991). Optimal penalties, criminal law and the control of corporate behavior. Boston University Law Review, 71, 395-419.

Burke, D., Nixon, M., Wilson, L., \& Higgins, S. (2009). Export controls and their effect on business operations. The Entrepreneurial Executive, 14, 1-23.

Burris, M. (2010). Tilting at windmills? The counterposing policy interests driving the U.S. commercial satellite export control reform debate. The Air Force Law Review, 66, 255-329.

Cinelli, G., \& Huffman, J. (2006). Outsourcing: Is it really worth the cost? Intellectual Property \& Technology Law Journal, 18, 21-23.

Cochran, P. L., \& Wood, R. A. (1984). Corporate social responsibility and financial performance. Academy of Management Journal, 27, 42-56. http://dx.doi.org/10.2307/255956

Czinkota, M., \& Dichtl, E. (1995). Export controls: Providing security in a volatile environment. The International Executive, 37, 485-495. http://dx.doi.org/10.1002/tie.5060370505 
Davidson III, W., \& Worrell, D. (1988). The impact of announcements of corporate illegalities on shareholder returns. The Academy of Management Journal, 31, 195-200. http://dx.doi.org/10.2307/256506

Davidson III, W., Worrell, D., \& Lee, C. (1994). Stock market reactions to announced corporate illlegalities. Journal of Business Ethics, 13, 979-987. http://dx.doi.org/10.1007/BF00881667

Department of state concludes settlement of export violations by Meggitt-USA, Inc. (2013). State Department Documents/FIND, August 23, 2013.

Dhaliwal, D. S., Li, O. Z., Tsang, A., \& Yang, Y. G. (2011). Voluntary Nonfinancial Disclosure and the Cost of Equity Capital: The Initiation of Corporate Social Responsibility Reporting. Accounting Review, 86(1), 59-100. http://dx.doi.org/10.2308/accr.00000005

Erickson, G. (1997). Export controls: Marketing implications of public policy choices. Journal of Public Policy \& Marketing, 16, 83-92.

Erickson, J. (2014). Stopping the legal flow of weapons: Compliance with arms embargoes, 1981-2004. Journal of Peace Research, 50, 159-172.

Export Controls: Agencies should assess vulnerabilities and improve guidance for protecting export-controlled information at universities (2006, December). GAO Report to the Committee on the Judiciary. House of Representatives.

Freixanet, J. (2012). Export promotion programs: Their impact on companies' internationalization performance and competitiveness. International Business Review, 12, 1065-1086. http://dx.doi.org/10.1016/j.ibusrev.2011.12.003

Frooman, J. (1997). Socially irresponsible and illegal behavior and shareholder wealth. Business and Society, 36, 221-249. http://dx.doi.org/10.1177/000765039703600302

Gleason, K., Malgwi, C., Mathur, I., \& Owhoso, V. (2005). Impact of perceived national corruption on the returns to U.S. multinationals in transactions with foreign governments. Review of Accounting and Finance, 4, 26-51. http://dx.doi.org/10.1108/eb043422

Godfrey, P., Merrill, C., \& Hansen, J. (2008). The relationship between corporate social responsibility and shareholder value: An empirical test of the risk management hypothesis. Strategic Management Journal, 30, 425-445. http://dx.doi.org/10.1002/smj. 750

Haslem, B. (2005). Managerial opportunism during corporate litigation. Journal of Finance, 60, 2013-2041. http://dx.doi.org/10.1111/j.1540-6261.2005.00786.x

Hunt, C. (2005). U.S. export controls and economic sanctions-An overview. Retrieved January 9, 2010, from http://files.ali-aba.org/thumbs/datastorage/skoobesruoc/pdf/Cl037-ch11_thumb.pdf

Introduction to the commerce department's export controls. (2007, March). Retrieved from http://www.bis.doc.gov

Karpoff, J., \& Lott, J. Jr. (1993). The reputational penalty firms bear from committing criminal fraud. Journal of Law \& Economics, 36, 757-802. http://dx.doi.org/10.1086/467297

Karpoff, J., Lee, D., \& Martin, G. (2011). Bribery penalties sting less than penalties for other financial misconduct. Foster School of Business, University of Washington. Retrieved January 13, 2013, from $\mathrm{http}: / /$ www.foster.washington.edu/centers/facultyresearch/Pages/bribery.aspx

Karpoff, J., Lee, D., \& Martin, G. (2013). The economics of foreign bribery: Evidence from FCPA enforcement $\begin{array}{lllll}\text { actions. } & \text { Retrieved } & \text { January } & 17, & \text { from }\end{array}$ http://papers.ssrn.com.portal.lib.fit.edu/sol3/papers.cfm?abstract_id $=1573222$

Kerber, R. (2003). Raytheon Co. assessed one of largest-ever penalties for export violations. Knight Ridder Tribune Business News, February 28, 2003.

Khanna, V. (2000). Corporate liability standards: When should corporations be held criminally liable? The American Criminal Law Review, 37, 1239-1283.

Lindsay, J. (1986). Trade sanctions as policy instruments: A re-examination. International Studies Quarterly, 30, 153-173. http://dx.doi.org/10.2307/2600674

McQuade, P., \& Geren, N. (2006). How to ensure that your off-shore preparation of US patent applications does not run afoul of US export controls. Intellectual Property \& Technology, 18, 8-13. 
McWilliams, A., \& Siegel, D. (2000). Corporate social responsibility and financial performance: correlation or misspecification? Strategic Management Journal, 21(5), 603-609.

Meschi, P. (2009). Government corruption and foreign stakes in international joint ventures in emerging economies. Asia Pacific Journal of Management, 26, 241-262. http://dx.doi.org/10.1007/s10490-007-9067-y

Milhollin, G. (2002). Export controls: Why we need them more than ever, Keynote address before the Practicing Law Institute. Retrieved from http://www.wisconsinproject.org/pubs/speeches/2002/12-9-02ecs.htm

Morris, M. (2006). The executive role in culturing export control compliance. Michigan Law Review, 104, $1785-1805$.

Nollen, S. (1987). Business costs and business policy for export controls. Journal of International Business Studies, 18, 1-18. http://dx.doi.org/10.1057/palgrave.jibs.8490396

Preston, L., \& O’Bannon, D. (1997). The corporate social-financial performance relationship. Business and Society, 36, 419-429. http://dx.doi.org/10.1177/000765039703600406

Robertson, C., \& Watson, A. (2004). Corruption and change: The impact of foreign direct investment. Strategic Management Journal, 25, 385-396.

Rogers, R. (2006). Fines for the unsuspecting. Strategic Finance, 87, 51-55.

Sakchutchawan, S. (2009). An inquiry into the strict compliance of the international chamber of commerce trade rules in financing process. Global Journal of International Business Research, 2, 1-16.

Senate Eases Export Limits on Some High-Tech Items. (2001, September 7). Wall Street Journal, A8.

Shulman, A. (2009). Testimony of Arthur Shulman in hearing on the Export Administration Act: A review of outstanding policy considerations. Before the House Committee on Foreign Affairs, Subcommittee on Terrorism, Nonproliferation, and Trade. Retrieved from http://www.internationalrelations.house.gov/111/shu070909.pdf

Slocum, J. (1997). Export Controls: Agencies Should Assess Vulnerabilities and Improve Guidance for Protecting Export-Controlled Information at Universities. The Journal of Research Administration, 38, 119-121.

Texas Company to Pay $\$ 100$ Million for Export Violations to Iran, Syria, Cuba, and Other Countries. (2013). Targeted News Service, November 26, 2013. Retrieved January 17, 2014, from http://search.proquest.com.portal.lib.fit.edu/docview/1461875938?accountid=27313

U.S. Department of Commerce, Bureau of Industry and Security, Export Enforcement. (2008). Don't Let This Happen to You! Retrieved January 9, 2010, from http://www.bis.doc.gov/complianceandenforcement/dontletthishappentoyou-2008.pdf

Viano, M., \& Arnold, J. (2006). Corporate criminal liability. The American Criminal Law Review, 43, 311-339.

Viscusi, W., \& Hersch, J. (1990). The market response to product safety litigation. Journal of Regulatory Economics, 2, 215-230. http://dx.doi.org/10.1007/BF00134061

Waddock, S., \& Graves, S. (1997). The corporate social performance-financial performance link. Strategic Management Journal, 303-319. http://dx.doi.org/10.1002/(SICI)1097-0266(199704)18:4<303::AID-SMJ869>3.0.CO;2-G

Waite, J., \& Schwartz, J. (2007). Enforcement activity mounts as Department of Justice focuses on exporters. Intellectual Property \& Technology, 19, 14-18.

Wei, S. (2000). Local corruption and global capital flows. Brookings Papers on Economic Activity, 2, 303-354. http://dx.doi.org/10.1353/eca.2000.0021

Wilkinson, T., \& Brouthers, L. (2006). Trade promotion and SME export performance. International Business Review, 15, 233-252. http://dx.doi.org/10.1016/j.ibusrev.2006.03.001

Note

Note 1. For complete information, see

http://www.bis.doc.gov/complianceandenforcement/dontletthishappentoyou-2008.pdf 


\section{Copyrights}

Copyright for this article is retained by the author(s), with first publication rights granted to the journal.

This is an open-access article distributed under the terms and conditions of the Creative Commons Attribution license (http://creativecommons.org/licenses/by/3.0/). 